\title{
LATIHAN ASERTIF TERHADAP PERKEMBANGAN IDENTITAS DIRI REMAJA
}

\section{ASSERTIVENESS TRAINING THERAPY TO ADOLESCENCE DEVELOPMENT}

\author{
Uswatun Hasanah \\ Akper Dharma Wacana Metro
}

\begin{abstract}
ABSTRAK
Usia remaja sangat labil dalam proses pencarian identitas diri. Hambatan dalam pencapaian identitas diri dapat menimbulkan perilaku menyimpang. Remaja dengan kesulitan bersikap asertif diberikan terapi Latihan Asertif. Tujuan penulisan yaitu menggambarkan hasil pelaksanaan Latihan Asertif terhadap peningkatan perkembangan remaja. Jenis penelitian ini kuantitatif dengan desain penelitian quasi eksperimen dengan pendekatan pre post test without control group. Sampel penelitian terdiri dari 16 remaja dengan metode pengambilan sampel yaitu purposive sampling. Evaluasi menunjukkan terjadi peningkatan aspek dan tugas perkembangan remaja, terutama pada aspek aspek emosi dan psikososial meningkat secara bermakna setelah mendapat Latihan asertif. Latihan asertif direkomendasikan sebagai terapi spesialis keperawatan jiwa dan disosialisasikan pada tatanan pelayanan kesehatan jiwa komunitas.
\end{abstract}

Kata Kunci: Identitas diri, remaja, Latihan asertif

\begin{abstract}
During adolescent age, the teenagers are struggling for their self identity. The obstacle of teenagers to gain their self identity to some extent can be manifested through their deviant behaviors. The purpose of this scientific paper was to explore the result of Assertiveness Training to improve adolescence growth and development. Teenagers with a difficulty of being assertive were given Assertiveness Training. This was a quasi-experimental research, using pre-post without control group. A number of 16 samples were recruited using purposive sampling technique. The results of these interventions showed the improvement particularl on diferrent aspects and developmental task of teenagers, especially in emotion and psychosocial aspecs. Assertiveness Training was recommended that this report would be utilized as a standard of mental health-psychiatric nursing specialized treatment and to be socialized at all community mental health care settings.
\end{abstract}

Key Words: Self-identity, Teenagers, Assertiveness Training 


\section{PENDAHULUAN}

Masalah kesehatan jiwa perlu menjadi fokus utama dalam setiap upaya peningkatan sumber daya manusia khususnya anak dan remaja, mengingat anak dan remaja merupakan generasi yang perlu disiapkan sebagai aset dan kekuatan bangsa. ${ }^{1}$ Jika ditinjau dari proporsi penduduk, $40 \%$ total populasi terdiri dari anak dan remaja berusia $0-16$ tahun. Prevalensi gangguan kesehatan jiwa anak dan remaja cenderung akan meningkat sejalan dengan permasalahan kehidupan dan kemasyarakatan yang makin komplek, oleh karena itu pelayanan kesehatan jiwa yang memadai sangat dibutuhkan sehingga memungkinkan remaja untuk mendapatkan kesempatan tumbuh kembang yang optimal. $^{2}$

Perkembangan merupakan proses yang dinamis dan berkelanjutan sepanjang kehidupan. Pada remaja terjadi kontradiksi antara pertumbuhan fisik dengan perkembangan sosial, psikologis, dan emosional, dimana pertumbuhan fisik remaja menyamai dan memiliki kemampuan seperti orang dewasa, namun secara sosial, psikologis, dan emosional masih labil serta masih memiliki ketergantungan yang tinggi. Kondisi ini sering menyebabkan remaja sulit menentukan identitas dirinya yang mengakibatkan remaja gagal dalam usaha pencarian dan pembentukan jati diri. Bila tugas perkembangan tidak dicapai, akan mengakibatkan kegagalan yang bersifat sebagian ataupun seluruhnya dalam pencapaian tugas-tugas lain yang dihadapi remaja. ${ }^{3}$ Situasi seperti ini menimbulkan konflik dan ketidakstabilan dalam pencapaian identitas diri yang mengakibatkan timbulnya berbagai masalah kesehatan remaja seperti perilaku kekerasan. ${ }^{4}$

Remaja dalam proses pencarian identitas dirinya banyak meniru, menilai dan mempersepsikan apa yang terjadi disekitarnya. Individu sebagai sistem personal memiliki persepsi, penilaian diri, dan gambaran diri sebagai hasil interaksi dengan orang lain dan lingkungan sepanjang usia tumbuh kembangnya. ${ }^{4}$ Banyak remaja yang mengatasi emosi dengan cara yang negatif seperti bertindak berlebihan di sekolah (bullying, tawuran) hingga tindakan-tindakan kriminal (seperti mencuri) serta pelanggaran-pelanggaran status seperti kabur dari rumah, dan membolos. ${ }^{5}$ Lewis (2001) menyatakan bahwa perilaku kekerasan bukanlah penyakit tetapi perilaku yang ditimbulkan dan mempunyai rentang intensitas dimulai dari membantah, menentang, menuntut, melakukan ancaman verbal, kontak fisik, 
brutal atau tawuran. Intensitas kejadiannya semakin sering pada anak pra sekolah dan mencapai puncaknya pada masa remaja tengah. ${ }^{6}$

Perilaku kekerasan rentan terjadi pada remaja, pada tahap perkembangannya, terutama jika terdapat faktor risiko yang menyertainya. Remaja yang rentan berperilaku kekerasan memiliki toleransi yang rendah terhadap frustasi dan kurang mampu menunda kesenangan, ${ }^{7}$ cenderung bereaksi dengan cepat terhadap dorongan agresinya, kurang dapat melakukan refleksi diri, ${ }^{8}$ dan kurang dapat bertanggung jawab atas akibat dari perbuatannya. ${ }^{9}$ Hal-hal tersebut tentu saja dapat mengganggu pencapaian identitas diri pada remaja.

Perilaku asertif merupakan suatu pengungkapan ekspresi secara langsung dan jujur yang memungkinkan remaja untuk mempertahankan hak-hak pribadinya tanpa melakukan tindakan agresif yang mengganggu hak-hak pribadi orang lain. Selain asertif terdapat juga perilaku pasif dan agresif. Pasif dimana individu tidak mampu menyampaikan apa keinginan ataupun pendapatnya. Sedangkan perilaku agresif cenderung menimbulkan perilaku kekerasan. Perilaku agresif diartikan sebagai tindakan yang dimaksudkan untuk melukai atau menyakiti orang lain, baik fisik maupun psikis, ${ }^{10,8}$ yang menimbulkan kerugian atau bahaya bagi orang lain atau merusak milik orang lain. ${ }^{11}$

Latihan asertif dilakukan berulangulang dan diterapkan ke remaja untuk menciptakan perilaku asertif, sehingga memerlukan bimbingan dan arahan secara intensif dari seorang terapis. ${ }^{12}$ Bentuk latihan stimulasi aspek emosi remaja adalah dalam bentuk Terapi asertif. ${ }^{13}$ Terapi ini melatih kemampuan seseorang untuk mengungkapkan pendapat, perasaan, sikap dan hak tanpa disertai adanya perasaan cemas. $^{14}$ Latihan Asertif telah diuji pada penelitian yang dilakukan oleh Novianti (2010), terbukti dapat melatih respon asertif dalam berbagai situasi. ${ }^{15}$ Penelitian yang dilakukan oleh Sert (2003) menyatakan bahwa latihan asertif secara signifikan dapat meningkatkan perilaku asertif. $^{16}$ Penelitian lain dilakukan oleh Agbakwuru dan Stella (2011) juga menyatakan hal senada bahwa latihan asertif memiliki efek positif dalam meningkatkan ketahanan diri remaja dimana ketahanan diri mempengaruhi koping seseorang. ${ }^{17}$

\section{METODE PENELITIAN}

Partisipan yang ikut dalam laporan ini adalah remaja sejumlah 16 orang. Pada remaja tersebut dilakukan pre test tentang aspek perkembangan remaja dan instrumen latihan asertif. Kemudian dilakukan latihan 
asertif dengan menggunakan buku kerja secara berkelompok yang terdiri dari 8 orang remaja masing-masing kelompok dan dilakukan selama lima minggu. Setelah dilakukan terapi, selanjutnya dilakukan post test tentang aspek perkembangan remaja dan evaluasi dengan menggunakan instrumen latihan asertif. Pelaksanaan terapi latihan asertif dilakukan dalam 5 sesi. Sesi I pemahaman asertif, pasif, agresif; sesi II melatih mengungkapkan pikiran dan perasaan negatif; Sesi III melatih menyampaikan keinginan dan kebutuhan; sesi IV melatih menyampaikan rasa kesalnya; Sesi V melatih mengatakan "tidak" untuk permintaan yang kurang rasional.

\section{HASIL PENELITIAN}

Asuhan keperawatan diberikan pada remaja dengan potensial pencapaian identitas diri remaja. Perjalanan panjang remaja dalam menerima stimulus di masa remaja akan dimunculkan dalam bentuk perilaku, baik itu adaptif maupun maladaptif. ${ }^{18}$ Perilaku yang dimunculkan tersebut merupakan mekanisme koping remaja untuk mempertahankan dirinya terhadap stimulus-stimulus yang diterimanya. Berikut akan dijelaskan bagaimana perilaku remaja dilihat dari 10 aspek perkembangan remaja.
Tabel 1

Karakteristik Aspek Perkembangan Remaja $(n=16)$

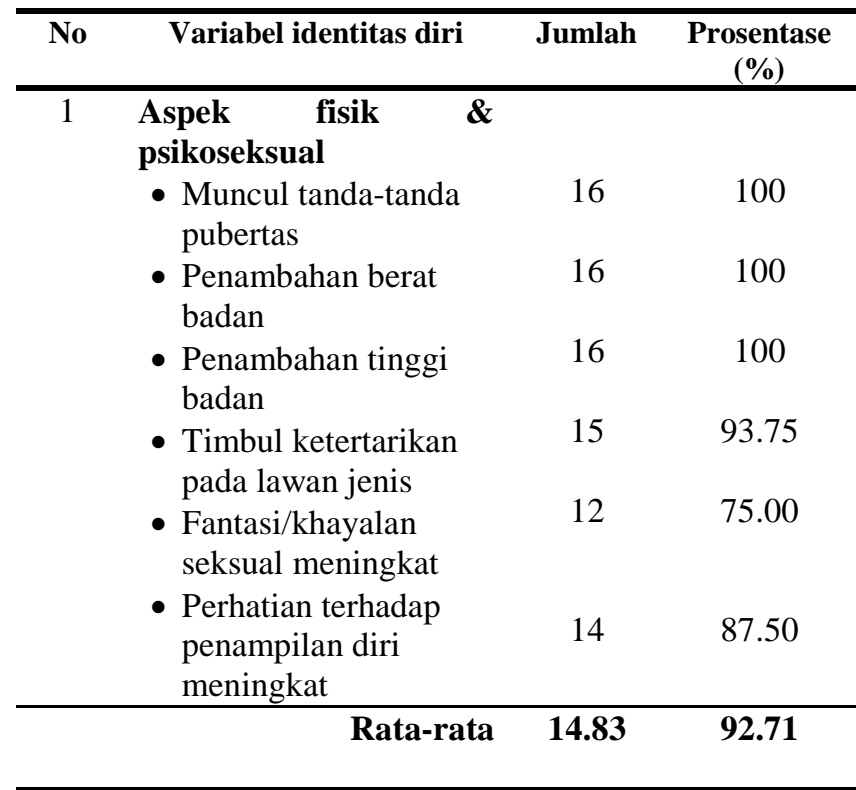

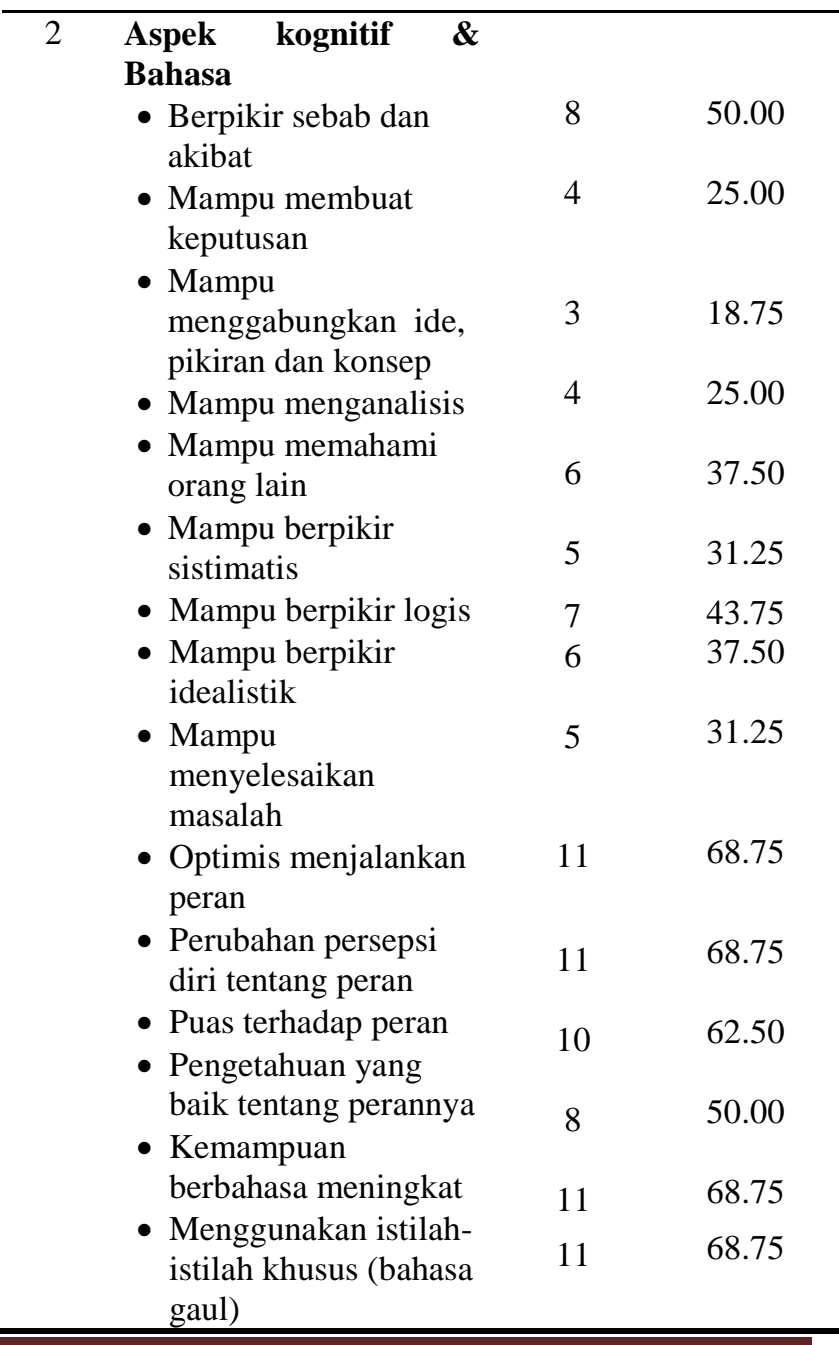




\begin{tabular}{|c|c|c|c|}
\hline & Rata-rata & 7.56 & 47.26 \\
\hline \multirow[t]{2}{*}{3} & $\begin{array}{l}\text { Aspek Moral \& } \\
\text { Spiritual } \\
\text { - Mengerti nilai-nilai } \\
\text { etika, norma agama } \\
\text { - Memperhatikan } \\
\text { kebutuhan orang lain } \\
\text { - Bersikap santun, } \\
\text { menghormati orang } \\
\text { tua dan guru } \\
\text { - Bersikap baik } \\
\text { terhadap teman } \\
\text { - Mulai taat pada aturan } \\
\text { dan tata tertib di } \\
\text { masyarakat } \\
\text { - Mulai rajin beribadah } \\
\text { sesuai agama yang } \\
\text { dianut } \\
\text { - Mau menjalankan dan } \\
\text { menjauhi larangan- } \\
\text { Nya }\end{array}$ & $\begin{array}{c}13 \\
12 \\
9 \\
14 \\
14 \\
15 \\
15\end{array}$ & $\begin{array}{l}81.25 \\
75.00 \\
56.25 \\
87.50 \\
87.50 \\
93.75 \\
93.75\end{array}$ \\
\hline & Rata-rata & 13.14 & 82.14 \\
\hline
\end{tabular}

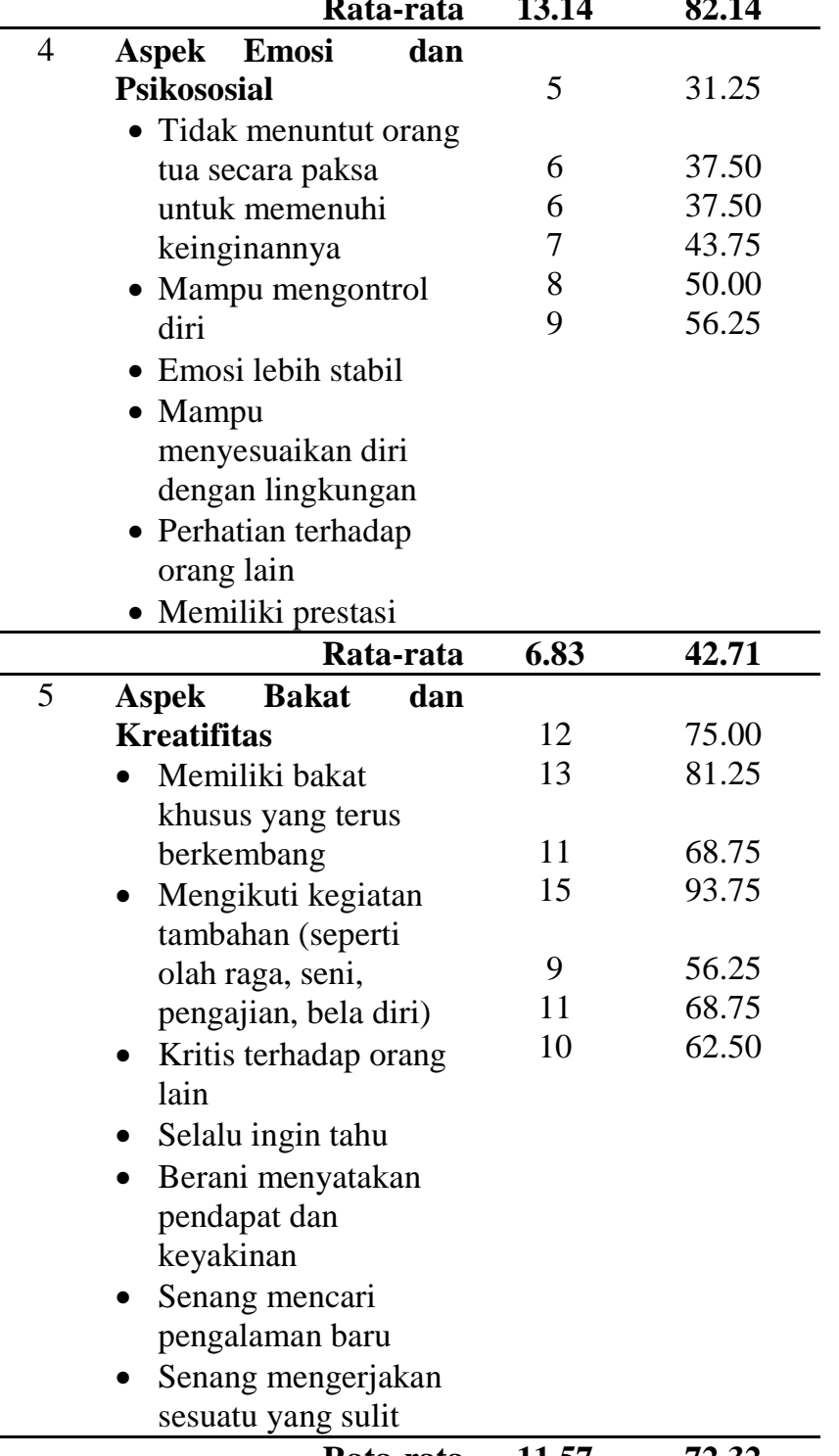

Kemampuan remaja sebelum diberikan terapi paling maksimal adalah Aspek fisik dan psikoseksual yang sudah mencapai $92.71 \%$, diikuti oleh kemampuan moral dan spiritual remaja sebesar $82.14 \%$. Kemampuan emosi dan psikososial sebelum terapi paling rendah yaitu sebesar $42.70 \%$. Sedangkan dua kemampuan lain yaitu kognitif dan bahasa juga masih kurang yaitu $47.26 \%$, inilah alasan mengapa perlu dilakukan terapi latihan asertif dalam menstimulasi tumbuh kembang remaja.

Terapi Asertif diberikan jika terdapat kondisi emosi remaja yang labil. Emosi yang labil pada remaja dapat disebabkan karena kemampuan menghadapi dan menyelesaikan konflik sosial masih kurang, oleh karena itu dibutuhkan terapi asertif dalam mengatasi masalah-masalah remaja. Setelah diberikan terapi, dapat dilihat bahwa pencapaian kemampuan aspek-aspek perkembangan remaja mengalami peningkatan. Hal ini terlihat pada tabel 2 . 
Tabel 2

Efektifitas Latihan Asertif Terhadap Pencapaian Identitas Diri Remaja

\begin{tabular}{|c|c|c|c|}
\hline \multirow{2}{*}{ No } & \multirow{2}{*}{$\begin{array}{c}\text { Aspek Perkembangan } \\
\text { Remaja }\end{array}$} & \multicolumn{2}{|c|}{ Sesudah } \\
\hline & & $\mathbf{J m h}$ & $\%$ \\
\hline \multirow[t]{8}{*}{1} & $\begin{array}{lll}\text { Aspek } & \text { fisik } & \&\end{array}$ & & \\
\hline & psikoseksual & & \\
\hline & $\begin{array}{l}\text { - Muncul tanda-tanda } \\
\text { pubertas }\end{array}$ & 16 & 100 \\
\hline & $\begin{array}{l}\text { - Penambahan berat } \\
\text { badan }\end{array}$ & 16 & 100 \\
\hline & $\begin{array}{l}\text { - Penambahan tinggi } \\
\text { badan }\end{array}$ & 16 & 100 \\
\hline & $\begin{array}{l}\text { - Timbul ketertarikan } \\
\text { pada lawan jenis }\end{array}$ & 16 & 100 \\
\hline & $\begin{array}{l}\text { - Fantasi/khayalan } \\
\text { seksual meningkat }\end{array}$ & 16 & 100 \\
\hline & $\begin{array}{l}\text { - Perhatian terhadap } \\
\text { penampilan diri } \\
\text { meningkat }\end{array}$ & 16 & 100 \\
\hline
\end{tabular}

\begin{tabular}{|c|c|c|c|}
\hline & Rata-rata & 16 & 100 \\
\hline \multirow[t]{16}{*}{2} & $\begin{array}{lll}\text { Aspek } & \text { kognitif } \quad \& \\
\text { Bahasa } & & \end{array}$ & & \\
\hline & $\begin{array}{l}\text { - Berpikir sebab dan } \\
\text { akibat }\end{array}$ & 16 & 100 \\
\hline & $\begin{array}{l}\text { - Mampu membuat } \\
\text { keputusan }\end{array}$ & 8 & 50.00 \\
\hline & $\begin{array}{l}\text { - Mampu } \\
\text { menggabungkan } \\
\text { ide, pikiran dan } \\
\text { konsep }\end{array}$ & 16 & 100 \\
\hline & $\begin{array}{l}\text { - Mampu } \\
\text { menganalisis }\end{array}$ & 16 & 100 \\
\hline & $\begin{array}{l}\text { - Mampu memahami } \\
\text { orang lain }\end{array}$ & 8 & 50.00 \\
\hline & $\begin{array}{l}\text { - Mampu berpikir } \\
\text { sistimatis }\end{array}$ & 8 & 50.00 \\
\hline & $\begin{array}{l}\text { - Mampu berpikir } \\
\text { logis }\end{array}$ & 16 & 100 \\
\hline & $\begin{array}{l}\text { - Mampu berpikir } \\
\text { idealistik }\end{array}$ & 7 & 43.75 \\
\hline & $\begin{array}{l}\text { - Mampu } \\
\text { menyelesaikan } \\
\text { masalah }\end{array}$ & 16 & 100 \\
\hline & $\begin{array}{l}\text { - Optimis } \\
\text { menjalankan peran }\end{array}$ & 16 & 100 \\
\hline & $\begin{array}{l}\text { - Perubahan persepsi } \\
\text { diri tentang peran }\end{array}$ & 16 & 100 \\
\hline & - Puas terhadap peran & 15 & 93.75 \\
\hline & $\begin{array}{l}\text { - Pengetahuan yang } \\
\text { baik tentang } \\
\text { perannya }\end{array}$ & 13 & 81.25 \\
\hline & $\begin{array}{l}\text { - Kemampuan } \\
\text { berbahasa } \\
\text { meningkat }\end{array}$ & 16 & 100 \\
\hline & - Menggunakan & 16 & 100 \\
\hline
\end{tabular}

istilah-istilah khusus $16 \quad 100$ (bahasa gaul)

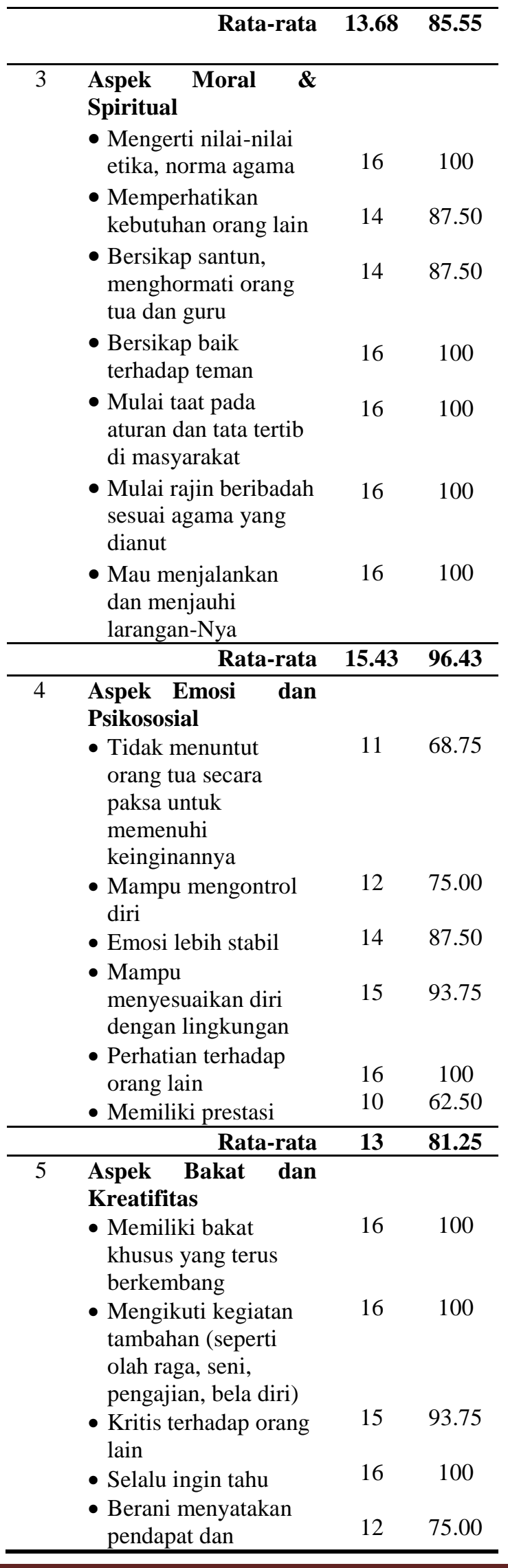


keyakinan

- Senang mencari

pengalaman baru

$15 \quad 93.75$

- Senang mengerjakan

sesuatu yang sulit

$14 \quad 87.50$

\begin{tabular}{lll} 
Rata-rata & $\mathbf{1 4 . 8 5} \quad \mathbf{9 2 . 8 6}$ \\
\hline
\end{tabular}

Pencapaian kemampuan remaja sebelum

dan sesudah terapi asertif terlihat dalam

tabel 3 .

Tabel 3

Kemampuan Remaja Sebelum dan Sesudah Terapi Asertif

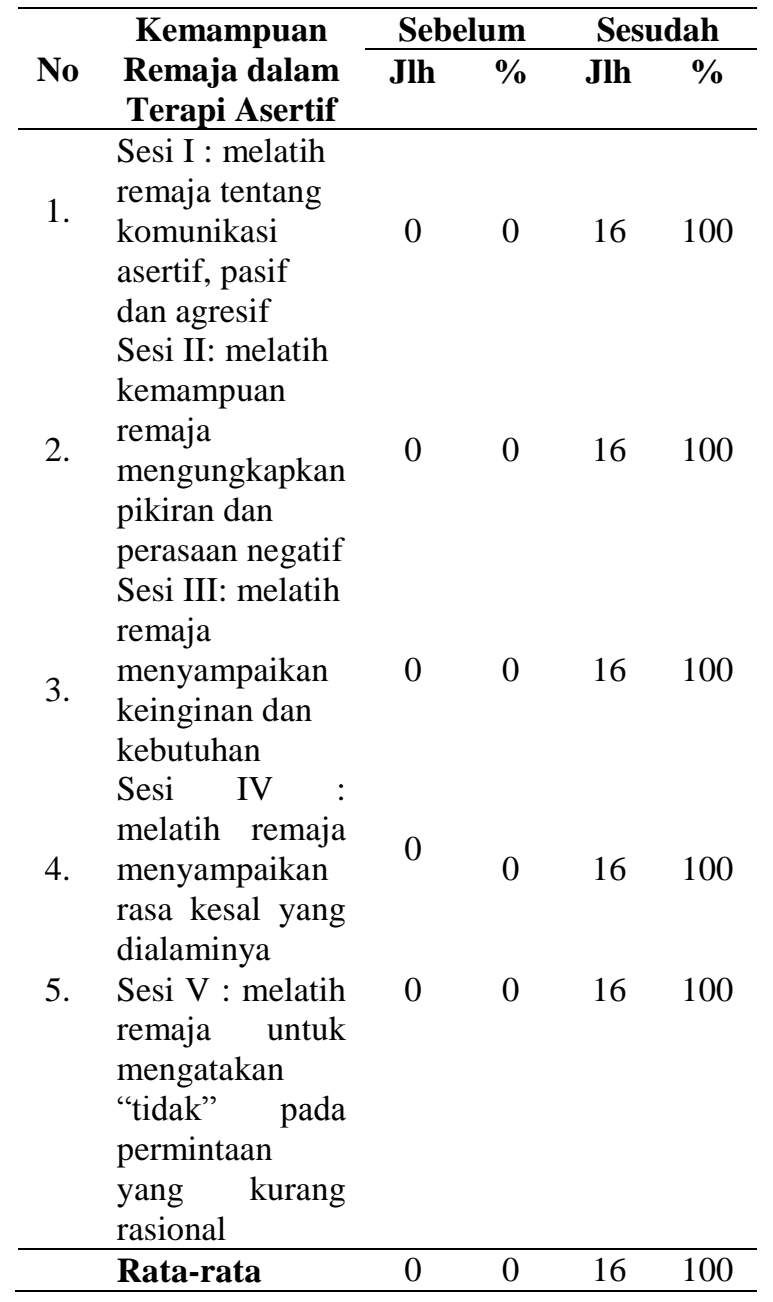

Outcome yang diharapkan setelah remaja mengikuti serangkaian program terapi spesialis sesuai kebutuhannya adalah perilaku sehat dilihat dari berbagai aspek perkembangan remaja. Berikut akan dijelaskan perbedaan kemampuan remaja dilihat dari aspek perkembangan remaja sebelum dan setelah pemberian terapi seperti terlihat pada tabel 4 .

\section{Tabel 4}

Perbedaan Kemampuan Remaja Sebelum Dan Setelah

Diberikan Terapi Asertif ( $n=16)$

\begin{tabular}{|c|c|c|}
\hline \multirow{2}{*}{\multicolumn{2}{|c|}{ Variabel Identitas Diri }} & \multirow{3}{*}{$\begin{array}{c}\text { Terapi Spesialis } \\
\begin{array}{c}\text { Terapi asertif } \\
(\%)\end{array} \\
92.71\end{array}$} \\
\hline & & \\
\hline \multirow{3}{*}{$\begin{array}{l}\text { Fisik \& } \\
\text { Psikoseksual }\end{array}$} & Sebelum & \\
\hline & Sesudah & 100 \\
\hline & Selisih & 7.29 \\
\hline \multirow{3}{*}{$\begin{array}{l}\text { Kognitif \& } \\
\text { Bahasa }\end{array}$} & Sebelum & 47.26 \\
\hline & Sesudah & 85.54 \\
\hline & Selisih & 38.28 \\
\hline \multirow{3}{*}{$\begin{array}{l}\text { Moral \& } \\
\text { Spiritual }\end{array}$} & Sebelum & 82.14 \\
\hline & Sesudah & 96.42 \\
\hline & Selisih & 14.28 \\
\hline \multirow{3}{*}{$\begin{array}{l}\text { Emosi \& } \\
\text { Psikososial }\end{array}$} & Sebelum & 42.70 \\
\hline & Sesudah & 81.25 \\
\hline & Selisih & 38.54 \\
\hline \multirow{3}{*}{$\begin{array}{l}\text { Bakat \& } \\
\text { Kreatifitas }\end{array}$} & Sebelum & 72.32 \\
\hline & Sesudah & 92.86 \\
\hline & Selisih & 20.53 \\
\hline
\end{tabular}

Berdasarkan tabel 4 dapat dilihat bahwa dari beberapa aspek perkembangan yang masih kurang sebelum pemberian terapi adalah aspek kognitif dan bahasa dengan rata-rata $47.26 \%$ dan aspek emosi dan psikososial dengan rata-rata $42.70 \%$. Setelah diberikan terapi asertif, dapat dilihat bahwa pencapaian kemampuan terbanyak adalah pada aspek emosi dan psikososial sebesar $38.54 \%$, diikuti oleh aspek kognitif dan bahasa naik sebesar $38.28 \%$. Berdasarkan terapi spesialis yaitu terapi asertif yang telah diberikan terlihat 
bahwa kemampuan remaja meningkat lebih besar.

\section{PEMBAHASAN}

Kemampuan remaja sebelum diberikan terapi paling maksimal adalah fisik dan psikoseksual yang sudah mencapai $100 \%$, diikuti oleh kemampuan moral dan spiritual remaja sebesar $96.42 \%$. Kemampuan emosi dan psikososial sebelum terapi paling rendah yaitu sebesar 42.70\%. Sedangkan dua kemampuan lain yaitu kognitif dan bahasa juga masih kurang yaitu $47.26 \%$.

Aspek fisik dan psikoseksual memiliki nilai yang tinggi sebelum diberikan terapi dikarenakan sebagian besar komponen aspek fisik dan psikoseksual sedang dialami remaja yaitu sudah muncul tanda-tanda pubertas, penambahan berat badan dan tinggi badan, timbul ketertarikan pada lawan jenis, memiliki fantasi/khayalan seksual, serta mulai memperhatikan penampilan diri. Pada remaja terjadi pertumbuhan fisik yang pesat, namun tidak diimbangi oleh perkembangan sosial, psikologis, dan emosional, dimana pertumbuhan fisik remaja menyamai dan memiliki kemampuan seperti orang dewasa, namun secara sosial, psikologis, dan emosional masih labil serta masih memiliki ketergantungan yang tinggi.
Respon kognitif mempunyai peran penting dalam proses adaptasi yang mempengaruhi dampak suatu kejadian yang penuh dengan stres dan memilih koping yang akan digunakan. ${ }^{18}$ Respon kognitif juga mempengaruhi seseorang dalam pengambilan keputusan dan perencanaan dalam hidupnya. ${ }^{19} \mathrm{Hal}$ senada juga dikatakan oleh Santrock (2007) yaitu remaja sudah mulai mempunyai pola berpikir untuk membuat suatu perencanaan untuk mencapai tujuan di masa depan. ${ }^{20}$ Piaget (1936 dalam Papilia, D.E., 1992) mengatakan bahwa pada masa remaja terjadi kematangan kognitif, yaitu terjadi interaksi dari struktur otak yang telah sempurna dengan lingkungan sosial yang semakin luas yangi memungkinkan remaja untuk berpikir abstrak. ${ }^{21}$ Pada tahap ini, remaja sudah mulai mampu berfikir tentang sesuatu dan sudah mulai membayangkan hal yang diinginkan di masa depan.

Salah satu tugas perkembangan yang harus dicapai remaja adalah mencapai kematangan emosi. $^{22}$ Hal ini sejalan dengan Hurlock (2008) yang mengatakan bahwa kematangan remaja mencakup pada kematangan emosional, seksual, sosial, dan fisik. Srivastava (2005) juga mengatakan hal yang sama bahwa kematangan emosi merupakan hal yang penting dalam masa peralihan remaja menuju tahap dewasa. ${ }^{19}$ 
Remaja dikatakan mencapai kematangan emosi ketika reaksi perasaan yang stabil terhadap suatu permasalahan sehingga untuk mengambil suatu keputusan atau melakukan sesuatu didasari dengan pertimbangan dan tidak mudah berubahubah. $^{23}$ Perilaku yang ditunjukkan dari kematangan emosi yaitu mampu menyatakan emosi secara konstruktif, mampu mencari solusi dari masalah yang dihadapi dengan cara-cara yang baik dan dapat diterima, serta diharapkan mampu menyeimbangkan antara pikiran dan perasaannya. $^{22}$

Setelah lima minggu lamanya diberikan terapi asertif, terlihat bahwa terjadi kenaikan yang cukup signifikan pada aspek emosi dan psikososial yaitu sebesar $38.54 \%$. Selain itu, aspek kognitif dan bahasa pun mengalami peningkatan sebesar $38.28 \%$. Terapi asertif lebih efektif jika dilakukan secara berkelompok. ${ }^{15}$ Terapi Asertif telah diuji pada penelitian yang dilakukan oleh Novianti (2010), terbukti dapat melatih respon-respon asertif dalam berbagai situasi. ${ }^{15}$ Penelitian lain dilakukan oleh Agbakwuru dan Stella (2012) juga menyatakan hal senada bahwa terapi latihan asertif memiliki efek positif dalam meningkatkan ketahanan diri remaja dimana ketahanan diri mempengaruhi koping seseorang. ${ }^{17}$
Terapi asertif dapat meningkatkan kematangan emosi remaja. Terdapat beberapa penelitian yang menghubungkan perilaku menyimpang remaja dengan kematangan emosi. Hasil penelitian yang dilakukan oleh Soetjiningsih (2010) menunjukkan bahwa tawuran, seks bebas, serta ketergantungan NAPZA yang terjadi di masa remaja merupakan perilaku yang mencerminkan ketidakmatangan emosi. Selain itu, terdapat juga hasil penelitian yang menunjukkan bahwa individu yang minum-minuman alkohol memiliki kematangan emosi yang rendah. $^{24}$ Penelitian Soetjiningsih (2010) juga menunjukkan bahwa semakin tinggi kematangan emosi remaja maka perilaku agresi akan semakin rendah. ${ }^{24}$

Hasil penelitian-penelitian tersebut sejalan dengan yang dikemukakan Sarwono (2011) bahwa salah satu penyebab tingginya perilaku menyimpang remaja adalah kurangnya kemampuan dalam mengendalikan emosi dan mengekspresikan emosi dengan cara yang dapat diterima norma, belum matangnya emosi individu menyebabkan individu mudah terbawa pengaruh lingkungan untuk melakukan suatu perbuatan. ${ }^{25}$

Pada hasil yang ditemukan dalam penelitian ini, didapatkan bahwa aspek kognitif dan emosi saling mempengaruhi satu sama lain yaitu didapatkan aspek 
emosi dan aspek kognitif yang sebelumnya memiliki nilai yang rendah akhirnya mengalami peningkatan setelah dilakukan terapi. Hasil ini sesuai dengan Soetjiningsih (2010) yang mengatakan bahwa perkembangan kognitif tidak terlepas dari perkembangan emosi remaja yang naik turun. Salah satu tugas perkembangan remaja yaitu kemampuan berpikir secara lebih dewasa dan rasional, memiliki pertimbangan yang lebih matang dalam penyelesaian masalah, memiliki tujuan dan merencanakan strategi. $^{24}$ Murniati dan Beatrix (2000) dalam penelitiannya menyatakan bahwa remaja masa sekarang lebih menekankan pada pemikiran dan tindakan yang mandiri dan inisiatif pribadi yang juga mengindikasikan kecenderungan untuk menempatkan kepentingan diri diataskepentingan kelompok. Hal ini menunjukkan bahwa remaja masih mementingkan aspek ego emosinya dalam mengambil suatu keputusan. Sehingga aspek kognitif dan emosi harus ditangani dengan baik karena keduanya saling mempengaruhi. ${ }^{26}$

\section{SIMPULAN}

Penelitian ini memberikan gambaran tentang manajemen kasus pada remaja yang diberikan terapi asertif. Terapi asertif diberikan pada 16 orang remaja. Terapiasertif dilakukan secara berkelompok. Terlihat dari pencapaian aspek kognitif dan bahasa naik sebesar $38.28 \%$, aspek emosi dan psikososial naik sebesar $38.54 \%$. Hasil pada peningkatan 10 aspek perkembangan didapatkan hasil lebih tinggi pada remaja setelah memperoleh Terapi Asertif.

\section{SARAN}

a. Remaja yang sudah diberikan terapi dapat menjadi peer conselor bagi remaja lain dengan pendampingan.

b. Pelayanan Keperawatan Jiwa hendaknya memfasilitasi dan mendukung pelaksanaan program Community Mental Health Nursing dengan instansi lain seperti Dinas Pendidikan dan Puskesmas.

c. Pelayanan Keperawatan Jiwa memberikan informasi dasar kepada kader kesehatan jiwa tentang tandatanda perilaku menyimpang pada remaja sehingga dapat menginformasikannya kepada perawat CMHN untuk ditindaklanjuti.

d. Perawat CMHN melakukan kerja sama antar program khususnya dengan pemegang program UKJS (Usaha Kesehatan Jiwa Sekolah) guna mendeteksi perilaku-perilaku remaja yang menyimpang, sehingga dapat ditindaklanjuti. 
e. Hasil temuan pada penelitian ini hendaknya dapat digunakan sebagai evidence based dalam mengembangkan terapi asertif pada berbagai kelompok usia khususnya remaja sehingga menjadi terapi modalitas keperawatan jiwa yang efektif dalam mencegah timbulnya masalah kesehatan jiwa dan meningkatkan kesehatan jiwa masyarakat.

\section{DAFTAR PUSTAKA}

1. Hamid, Achir,Y.(2009). Bunga rampai asuhan keperawatan kesehatan jiwa. Edisi 1. Jakarta : EGC

2. Walker, J. W. (2002). Human Resourcing Planning. New York: McGraw-Hill, Inc.

3. Agustiani, H. (2006). Psikologi Perkembangan: Pendekatan Ekologi Kaitannya dengan Konsep Diri dan Penyesuain Diri pada Remaja. Bandung: PT. Refika Aditama.

4. Tomey, M \&Alligood (2006). Nursing Theorist and Their Work. $6^{\text {th }}$ edition. St.Louis: Mosby-Year Book, Inc.

5. Sarwono, S.W. (2011). Psikologi remaja. Edisi 14. Jakarta : PT Raja Grafindo Persada

6. George, Julis B. (1995). Nursing Theories: the base for professional nursing practice, $3^{\text {rd }}$. Connecticut: Applenton \& Lange.

7. Myers, D. . (2002). The cognitive basis of trait anger and reactive aggression: An integrative analysis. Society for Personality and Social Psychology, 12(1), 3- 21.

8. Larson, J. (2008). Angry and aggressive students. Principal Leadership, 8 (5), 12- 15.

9. Knorth, E.J., Klomp, M., Van der Bergh, P. M., \& Noom, M. J. (2007).
Aggressive adolescents in residential care: A selective review of treatment requirements and models. Adolescence, 42 (167), 461-485.

10. Berkowitz, L. (2003). Affect, aggression, and antisocial Behavior. Dalam Davidson, R.J, Scherer, K.R., Goldsmith, H.H. Handbook of Affective Sciences. Oxford: University Press. Hlm. 804-823.

11. Franzoi, S. L. (2009). Social psychology (5th ed.). New York: McGraw Hill Company.

12. Safaria,T \& Eka,N.S. (2009). Manajemen Emosi. edisi 1. Jakarta : PT Bumi Aksara.

13. Townsend \& Mary (2009). Psychiatric Mental Health Nursing. (6th Ed.). Philadelphia: F.A. Davis Company

14. Hall, C. S. \& Lindzey, G. 1993. Psikologi Kepribadian 1: Teori-Teori Psikodinamik (Klinis). Yogyakarta: Kanisius. Editor: A. Supratiknya.

15. Novianti. (2010). Pengaruh terapi kelompok Assertiveness Training terhadap kemampuan komunikasi ibu dalam mengelola emosi anak usia sekolah (7-12 tahun) di Kelurahan Balumbang Jaya Kota Bogor tahun 2010. Tesis S2 (tidak dipublikasikan. Jakarta : Keperawatan Universitas Indonesia.

16. Srivastava, S. K. (2005). Organizational Behaviour and Management. New Delhi: Sarup \& Sons.

17. Agbakwuru, C., \& Stella, U. (2012). Effect of assertiveness training on resilience among early-adolescents. European Scientific Journal VO - 8, $8(10), 69$. Retrieved from https://login.ezproxy.net.ucf.edu/login ?auth=shibb\&url=http://search.ebscoh ost.com/login.aspx?direct=true $\& \mathrm{db}=\mathrm{e}$ dsgao\&AN=edsgcl.348453037\&site $=e$ ds-live \&scope $=$ site

18. Stuart,G.W \& Laraia, M.T (2009). Principles and Practice of psychiatric 
nursing. (8th edition). St Louis: Mosby

19. Santrock, J. . (2007). Adolescence chapter 1 (11th ed.). Dalas: McGrawHill Companies Inc.

20. Smith, D. G., Xiao, L., \& Bechara, A. (2012). Decision making in children and adolescents: impaired Iowa Gambling Task performance in early adolescence. Developmental Psychology, 48(4), 1180-7. https://doi.org/10.1037/a0026342

21. Papilia, D.E., Sally Wendkos Olds, 1992, Human Development, McGrawHill, Inc., New York

22. Yusuf, S. (2004). Psikologi Perkembangan Anak dan Remaja. Bandung: PT Remaja Rosdakarya.

23. Hurlock, E.(2008). Perkembangan anak jilid 1. Edisi 6. Jakarta : Erlangga.

24. Soetjiningsih. (2010). Tumbuh Kembang Remaja Dan Permasalahannya. Jakarta: CV Sagung Seto.

25. Sarwono, S. . (2011). Psikologi remaja (14th ed.). Jakarta: PT Raja Grafindo Persada.

26. Murniati, J. \& Beatrix Sophie. (2000). Perbedaan nilai remaja sekarang dengan generasi sebelumnya. Fakultas Psikologi UI. Jurnal Psikologi Sosial VII: 59-64 